\title{
STUDENTS' PERCEPTION ON THE EFFECTIVENESS OF TEACHING ESP FOR SOCIAL AND POLITICAL SCIENCE PROGRAM
}

Nensy Triristina;Darul ‘Ulum University Samsul Khabib $\bowtie$; Universitas PGRI Adi Buana Surabaya

\begin{abstract}
This study investigates ESP students' perception of ESP teaching effectiveness for Social and Political Science from the non -English Department. Data were collected from forty -six participants from three Social and Political Science Program Departments, Darul 'Ulum University. To obtain the data, questionnaires and interviews were employed as the instruments. Furthermore, the data were analyzed using descriptive analysis into four categories; material, teaching method, learning motivation, and classroom management. The findings showed that some students $\mathrm{w}$ ere dissatisfied with the ESP materials given. However, the students perceived that they need to take the ESP materials to have professional communication skills for future careers. Additionally, it was also found that the roles of lectures' guidance in le arning ESP were important. Finally, the interview results reveal the difficulties the students face in learning ESP, including vocabulary, pronunciation, reading comprehension, and grammatical structure.
\end{abstract}

Keywords: Teaching ESP, ESP for Social and Political Science Program, effectiveness.

$\bowtie$ samsulkhabib@unipasby.ac.id

Citation: Triristina, N. \& Khabib, S. (2021). Students' perception on the effectiveness of teaching esp for social and political science program . Social Sciences, Humanities and Education Journa l (SHE Journal), 2(2), 83 - 95. DOI: 10.25273/she.v2i2.9228

\section{(c) EY-NC-SA}

Published by Universitas PGRI Madiun. This work is licensed under the Creative Commons Attribution-NonCommercialShareAlike 4.0 International License. 


\section{INTRODUCTION}

The English language that is taught in a formal education varies depending on the level of education. General English is generally taught at the elementary, junior, and senior high school levels, while English for Specific Purposes (ESP) is typically taught at the university level and is taught in relation to a specific major. The aim of ESP is to provide students with English that is relevant to their fields of study. Thus, ESP is also known as a teaching method that focuses on the needs of students with a certain purpose.

Teaching ESP to non-English students at the Faculty of Social and Political Science, Darul 'Ulum University, as a general course necessitates them understanding English terms specific to their area.. Besides, according to Salkind and Rasmussen (2008), learning English at higher education emphasizes reading skills more than any other ability since students must read a variety of lecture materials in English that are relevant to the topic.

A good and competent lecture is encouraged to make materials to fit the students' needs. However, in developing or designing the materials, some factors should be considered. According to McDonough, Shaw, and Masuhara (2013), a lecture should be guided by a syllabus in teaching materials. It is derived from the goals which want to be achieved in the language program. The goal is formed by the language teaching program's natural context: the students themselves and the educational setting where the teaching will occur.

Based on the researcher's observation, teaching ESP in the Social and Political Science Program was found to be challenging. Most students still lack the competence to communicate English effectively despite learning it for six years in junior and senior high schools. They got difficulties to use the vocabulary and structure that they have to learn in an ESP context. Consequently, the students felt unmotivated to learn ESP.

The previous research was conducted by Germizaj and Hoxha (2014) who investigated ESP course content's effectiveness for the Faculty of Philology and Faculty of Economic. They discovered that ESP courses are important in course assessment, with the goal of empowering students as participants in the learning process. Furthermore, ESP courses should be recommended at the university level to replace general courses because they are more concentrated and provide grounds for students' increased success rate. Rahmi, Abduh, and Sofyan (2019) stated the students' perceptions about the textbook they use in ESP business class weeks material related to Busi stateless English vocabulary, grammar/ language structure, and functional language teaching. The design or appearance of books to be less attractive making them less interested in using the book. They suggested that teaching strategies implemented by ESP Business English lecture should be created fun learning.

Considering these phenomena, investigating students' perception of teaching ESP in the non-English department is significant. In addition, the researcher formulated the following research questions: 1) What is the student's perception of the effectiveness of teaching ESP for the Social and Political Science Program? Furthermore, 2) What are the students' difficulties in learning ESP for the Social and Political Science Program?

\section{LITERATURE REVIEW}

\section{English Specific Purposes (ESP)}

The word specific in ESP refers to the specific purpose for learning English. According to Ahmed (2014), ESP stands for English language teaching that is tailored to meet the needs of students in a specific area. Richards (2001) also 
stated that ESP is an approach to language designed to make language courses more relevant to the students' needs. It is in line with Fiorito (2021), who explained that ESP aims to develop student's language skills in professional communication.

According to Arnó-Macià and Mancho-Barés (2015), ESP focuses on language in meaning rather than teaching grammar and language structures. One of the most critical aspects of ESP is that English is not taught as a separate topic from the students' everyday lives, but rather as part of a subject matter field that is important to them. English skills should be emphasized in students studying for graduate work in the social and political science program, according to ESP. For example, it encourages students who want to be ambassadors, leaders, or other public figures to improve their speaking skills. Based on the above explanation, it seems that ESP is goaloriented, since it is tailored for individual students based on their academic and developmental needs.

\section{ESP Courses for Social and Political} Science Program

The ESP courses at Darul 'Ulum University's Social and Political Science Program are offered in the first and second years, specifically in the first and fourth semesters of the Bachelor's degree program. It is divided into two, namely basic English by the course's name is 'Bahasa Inggris' and 'Bahasa Inggris II.' In the first semester, Bahasa Inggris is a compulsory course for all departments consist of Public Administration, International Relation, and Sociology, whereas in the fourth semester, Bahasa Inggris II is compulsory for the Department of International Relation. The course's goal is to provide students with information and skills. This will allow them to understand and interact with written text in their field of work, as well as communicate fluently in both speaking and writing for professional purposes.
The first-year and second-year courses have different topic-based syllabuses. The first course examines a variety of social and political issues: Introduction to Political and Social Sciences (Politic, International Relations, Sociology), Democracy, Monarchy, Feudalism, Capitalism, Communism, Globalization, Nationalism, Socialism. These are broad topics designed to introduce students to key concepts in their field of study in order to expand their vocabulary and develop their language skills. Meanwhile, the second course delves further into topics relevant to the Department of International Relations like Culture and Democracy, International Policy, International Political Law, International Legal treaties, Globalization impact on SocioCulture, Racial discrimination.

The course content, which includes autonomous learning and interaction individually and in groups, is fully in compliance with the student's needs and ESP courses' general principles. It provides an opportunity for building and expanding specialized vocabulary and acquiring knowledge and skills in conducting social and political text. Upon completing the course, students are expected to participate in discussions, presentations and write an essay. ESP and general courses both cover grammar and roles, general vocabulary, and anxiety about skills, as well as daily English, small talk, travel vocabulary, survival English, and current affairs (Agustina 2014).

\section{Effective Method for Teaching ESP}

ESP teaching-learning purposes are communicative competence. To achieve the students' needs, teaching ESP should be based on the basic concept of the target students' core language needs, which should be aided by the use of teaching materials and practice (Poedjiastutie and Oliver 2017). However, it provides students' needs, and communicative activities should include the ESP approach's emphasis. 
Effective teaching ESP in the classroom involves a student-oriented and learning process. It is a type of instruction that can inspire students, provide knowledge, communicate concepts, and assist students with learning disabilities. According to (Souriyavongsa et al. 2013), College teaching necessitates a thorough understanding of the information to be communicated as well as how to explain it to students. As a result, college ESP classes place a greater emphasis on current awareness, discussion, and presentation. Furthermore, successful teaching ESP provided by the lecture is expected to be able to handle the learning process in order to motivate students to learn by inspiring them and acknowledging their challenges.

According to Young and Shaw (1999), as cited in (Devlin and Samarawickrema 2010), ineffective teaching has six components: 1) the importance of teaching materials, 2) motivated students, 3) a friendly classroom setting, 4) the composition of teaching materials, 5) effective communication, and 6) a studentcentered approach. Furthermore, success is dependent on both human and nonhuman factors. Human elements are linked to the positions of the lecturers as well as the characteristics of the students. Human elements also involve the contact between students and lecturers in the classroom. Meanwhile, non-human components include textbooks, syllabi, teaching aids, and hours. Those elements have the potential to be difficult to teach ESP effectively. The aspects in teaching ESP, such as materials development and class management, and evaluation mechanism, are all conducted by the lecture. Besides, the roles of lecture in ESP are not only as a teacher but also as researcher, collaborator, motivator, and evaluator. Following the materials designer, the lecture has to determine and select the appropriate materials to emphasize teaching ESP. Besides, it needs to modify and add the current materials to make them more appropriate to the students' needs (Syarifah 2017). ESP lecture also needs to reinforce additional materials to support the main textbook, covering all materials related to students' needs.

For both students and teachers to participate in teaching and learning events, effective teaching is critical. As a result, effective teaching must completely engage students, as learning emphasizes both outcomes and the learning process. In other words, the lecture has to focus on the students during the learning process.

\section{METHOD}

The method used in this study is a case study concerned with exploring students' perceptions on the effectiveness of teaching ESP for the Social and Political Science program. The population of this study was all students of the 2020/2021 academic year. The sample was taken only 46 participants from three departments of the Social and Political Science Program, Darul 'Ulum University, who have already taken English courses in the first semester. They were selected at random to represent each faculty's entire student body.

There are two instruments used in the study: questionnaire and interview. The students were asked to fill in an online questionnaire distributed to know their opinion toward teaching ESP for the Social and Political Science Program. Forty questions about the curriculum, the learning process, learning motivation, and classroom management were asked of the students. The questions used English, although the respondents coming from the department are not of English Department.

The research data were obtained from the questionnaire filled out by respondents and the interview method. The interview was the interviewees' statements in response to the questions about the difficulties in learning ESP. The 
data analysis technique was carried out by analyzing the results of questionnaire evaluations and the interviews' results, then presented in numerical data and description.

\section{RESULTS AND DISCUSSION}

The Students' Perception on the Effectiveness Teaching ESP

The findings in the tables below show how students feel about teaching ESP in general.

\section{The Material}

The students' opinions on the ESP materials presented by the lecture in teaching ESP are as follows.

TABLE 1. Students' Perception about ESP Material

\begin{tabular}{|c|c|c|c|c|}
\hline \multirow{2}{*}{$\begin{array}{l}\mathrm{N} \\
\mathrm{O}\end{array}$} & \multirow[t]{2}{*}{ Item } & \multicolumn{3}{|c|}{ Option (\%) } \\
\hline & & $\begin{array}{c}\text { Agre } \\
\text { e }\end{array}$ & $\begin{array}{c}\text { Disagre } \\
\mathrm{e}\end{array}$ & $\begin{array}{c}\text { Neutr } \\
\text { al }\end{array}$ \\
\hline 1 & $\begin{array}{l}\text { The learning } \\
\text { goal is clear }\end{array}$ & $\begin{array}{c}68.9 \\
\%\end{array}$ & $2.2 \%$ & $28.9 \%$ \\
\hline 2 & $\begin{array}{l}\text { The material } \\
\text { given during } \\
\text { a semester } \\
\text { runs } \\
\text { smoothly }\end{array}$ & $\begin{array}{c}62.9 \\
\%\end{array}$ & $2.2 \%$ & $35.6 \%$ \\
\hline 3 & $\begin{array}{l}\text { Additional } \\
\text { materials } \\
\text { (such as } \\
\text { textbook, } \\
\text { PowerPoint, } \\
\text { video) help } \\
\text { the students } \\
\text { to increase } \\
\text { understandi } \\
\text { ng in } \\
\text { learning } \\
\text { English }\end{array}$ & $\begin{array}{c}84.4 \\
\%\end{array}$ & $2.2 \%$ & $13.3 \%$ \\
\hline 4 & $\begin{array}{l}\text { The material } \\
\text { relates to } \\
\text { students' } \\
\text { need }\end{array}$ & $80 \%$ & $6.7 \%$ & $13.3 \%$ \\
\hline 5 & $\begin{array}{l}\text { The material } \\
\text { is } \\
\text { interesting }\end{array}$ & $\begin{array}{c}46.7 \\
\%\end{array}$ & $6.7 \%$ & $46.7 \%$ \\
\hline 6 & $\begin{array}{l}\text { The material } \\
\text { is easy }\end{array}$ & $6.7 \%$ & $40 \%$ & $53.3 \%$ \\
\hline 7 & $\begin{array}{l}\text { The lecturer } \\
\text { guides the } \\
\text { students }\end{array}$ & $\begin{array}{c}93.3 \\
\%\end{array}$ & $2.2 \%$ & $4.4 \%$ \\
\hline
\end{tabular}

\begin{tabular}{|c|c|c|c|c|}
\hline \multirow{2}{*}{$\begin{array}{l}\mathrm{N} \\
\mathrm{o}\end{array}$} & \multirow[t]{2}{*}{ Item } & \multicolumn{3}{|c|}{ Option (\%) } \\
\hline & & $\begin{array}{c}\text { Agre } \\
\text { e }\end{array}$ & $\begin{array}{c}\text { Disagre } \\
\mathrm{e}\end{array}$ & $\begin{array}{c}\text { Neutr } \\
\text { al }\end{array}$ \\
\hline 8 & $\begin{array}{l}\text { The material } \\
\text { given is } \\
\text { understandi } \\
\text { ng }\end{array}$ & $\begin{array}{c}11.1 \\
\%\end{array}$ & $13.3 \%$ & $75.6 \%$ \\
\hline 9 & $\begin{array}{l}\text { The material } \\
\text { helps to } \\
\text { stimulate } \\
\text { students' } \\
\text { motivation }\end{array}$ & $\begin{array}{c}48.9 \\
\%\end{array}$ & $11.1 \%$ & $40 \%$ \\
\hline $\begin{array}{l}1 \\
0\end{array}$ & $\begin{array}{l}\text { The lecturer } \\
\text { reviewed } \\
\text { the material } \\
\text { every } \\
\text { meeting }\end{array}$ & $\begin{array}{c}84.4 \\
\%\end{array}$ & 0 & $15.6 \%$ \\
\hline
\end{tabular}

Data analysis in Table 1. presented that $68.9 \%$ of students agreed that the lecture's purpose was clear and ran smoothly in one semester. The material was provided in order to improve the students' understanding of learning ESP. Similarly, the material was described as related to students' needs in social and political science. Its aim was to encourage students to use English in both academic and professional settings. Therefore, both ESP and materials were based on analyzing the students' needs (Basturkmen and Oliver 2006). However, almost $50 \%$ of students agreed that the given ESP material stimulated their motivation, although $53.3 \%$ disagreed that the material given was not easy.

Besides, $84.4 \%$ of students agreed that the lecture should evaluate to know the students' understanding. As a result, it appeared that reviewing the content at each meeting was a concern for the lecture. The lecture is also expected to understand the classroom problems and know the kind of evaluation relevant to her students.

The students had difficulties reading and interpreting content because they lacked vocabulary and grammar skills, which they had described and demonstrated. They did not know the meaning of vocabulary in reading text. Therefore, they were lazy to think deeply about how to relate the vocabulary with 
the context. It displayed that $75.6 \%$ of students presumed the material given in the class was not understanding. These problems have been due to the same as the reason proposed by Alqahtani (2015), he discovered that their difficulty in learning a language was due to a lack of vocabulary. The students struggled to determine the correct interpretation of the words depending on the context.

The materials are used to supplement language instruction, and their nature is an integral part of ESP teaching (Bojović 2006). Table 1. also presents that $84.4 \%$ of students agreed on additional materials such as textbooks, PowerPoint, and video helped the students increase understanding in learning ESP. According to Hyland (2011), the content can include audio and visual aids, computer and Internetmediated tools, actual objects, or performance, despite being primarily paper-based. Since the aim of ESP material is to introduce students to the real language used in a variety of professional and academic settings, they are presented to stimulate students' imagination, preparation, and interaction with others.

\section{Teaching Method}

The students' perceptions of the lecture's teaching method in teaching ESP are shown in the table below.

TABLE 2. Students' Perception about ESP Teaching Method

\begin{tabular}{|c|c|c|c|c|}
\hline $\mathrm{N}$ & \multirow[t]{2}{*}{ Item } & \multicolumn{3}{|c|}{ Option (\%) } \\
\hline 0 & & Agree & $\begin{array}{c}\text { Disagre } \\
\mathrm{e}\end{array}$ & $\begin{array}{c}\text { Neutra } \\
l\end{array}$ \\
\hline 1 & $\begin{array}{l}\text { The } \\
\text { lecturer } \\
\text { introduces } \\
\text { the } \\
\text { syllabus } \\
\text { and } \\
\text { explains } \\
\text { the } \\
\text { learning } \\
\text { contract at } \\
\text { the } \\
\text { beginning } \\
\text { of the }\end{array}$ & $\begin{array}{c}93.3 \\
\%\end{array}$ & 0 & $6.7 \%$ \\
\hline
\end{tabular}

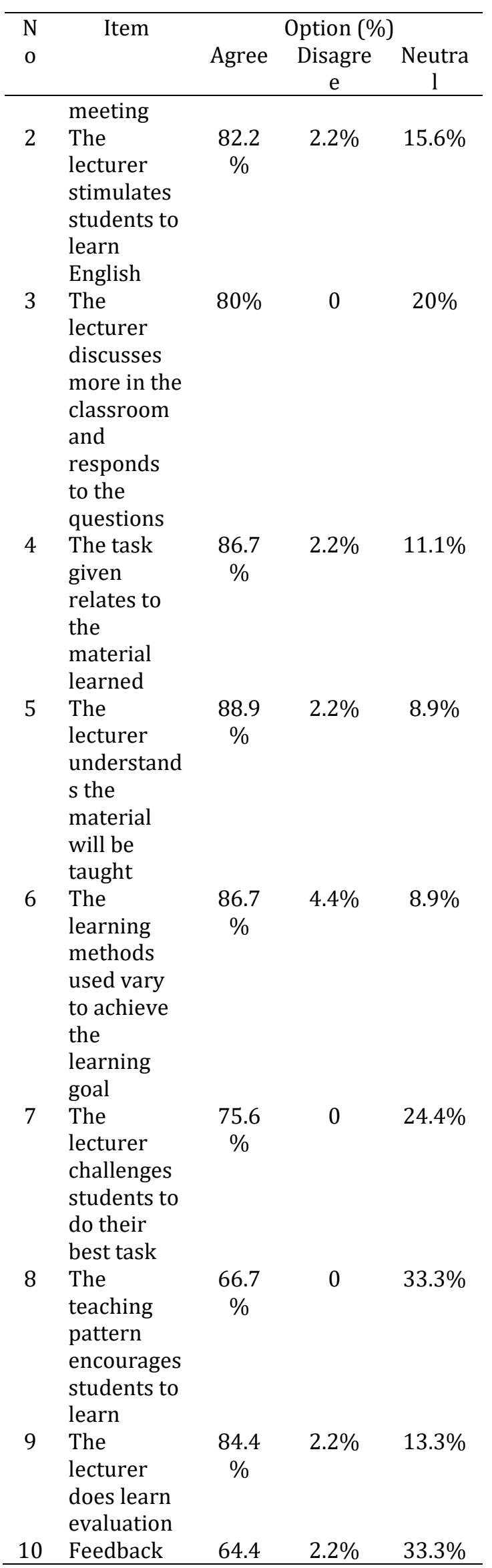




\begin{tabular}{|c|c|c|c|c|}
\hline $\mathrm{N}$ & \multirow[t]{2}{*}{ Item } & \multicolumn{3}{|c|}{ Option (\%) } \\
\hline o & & Agree & $\begin{array}{c}\text { Disagre } \\
\mathrm{e}\end{array}$ & $\begin{array}{c}\text { Neutra } \\
1\end{array}$ \\
\hline & $\begin{array}{l}\text { given } \\
\text { enable to } \\
\text { increase } \\
\text { students' } \\
\text { motivation }\end{array}$ & $\%$ & & \\
\hline
\end{tabular}

The students accepted that the lecturer should have presented the syllabus and clarified the learning contract at the start of the meeting, as shown in Table 2 . with $93.3 \%$. It is important to give information on teaching the ESP process, which was presented in one semester. It means that the teaching methods used vary in order to achieve the ESP learning goal. There were $86.7 \%$ of students agreed with the method. Nearly $90 \%$ of students agreed that the lecture stimulated the students to respond to the topic course questions.

Moreover, $88.9 \%$ of students concluded that the lecturer had a thorough understanding of the subject, and $86.7 \%$ of them also agreed the lecture gave the task under the material. It is associated with the lecture's roles; ESP lecture should be aware of the course objectives, have a good understanding of the course content, and be flexible with students. Besides, almost $80 \%$ of students agreed that the lecture challenged them to do their best work and conduct learning evaluations. The challenge is provided as the reward for the score. It is in line with nearly $70 \%$ of students who agreed that the lecture's teaching pattern and feedback increase students' motivation.

From the finding above, it could be concluded that the lecture managed the situation in teaching the ESP process attractively. She may use a number of techniques to support students who are having trouble learning ESP. She used the traditional approach, but she tweaked the techniques by providing input with a reward based on the score at each meeting. Besides, the lecture made questions through games activity related to the topic before class. It ensured that the students were not bored. in the learning process.

In summary, Fatmawati, Gani, and Samad (2018) applied that the various strategies create an attractive atmosphere in the teaching-learning process, such as the lecture's giving the students the information, experiences, and cognitive process. From that description, the lecture used strategies to enrich the students' information related to the material. Lectures' competence in teaching ESP is essential since they are the motor generating other main components in conducting ESP class, namely material and evaluation (Akhiroh 2017).

It was displayed $88.9 \%$ of students agreed that the lecturer understood the material would be taught. From the data, the lecture had prepared and selected the effective lessons to be used as the instruction materials purposefully, thoughtfully, and precisely. (Vong and Kaewurai 2017) stated that materials strategies directly focus on developing students' thinking based on the instructional process. The strategies for teaching and learning cannot be separated. It means that the lecture with a strategic understanding of instructional variables and cognitive requirements in learning will have a good management time and style.

\section{Learning Motivation}

The table below depicts the students' inspiration for learning ESP.

TABLE 3. Students' Perception about

\begin{tabular}{ccccc}
\multicolumn{4}{c}{ Motivation in Learning ESP } \\
\hline $\mathrm{N}$ & \multicolumn{1}{c}{ Item } & \multicolumn{3}{c}{ Option (\%) } \\
$\mathrm{o}$ & & Agree & Disagree & Neutral \\
\hline 1 & I learn & 64.4 & $6.7 \%$ & $28.9 \%$ \\
& English to & $\%$ & & \\
& help & & & \\
& understan & & & \\
& d & & \\
& literature, & & \\
& book, & & \\
& journal, & & \\
& news, & & \\
& speech, & & \\
&
\end{tabular}




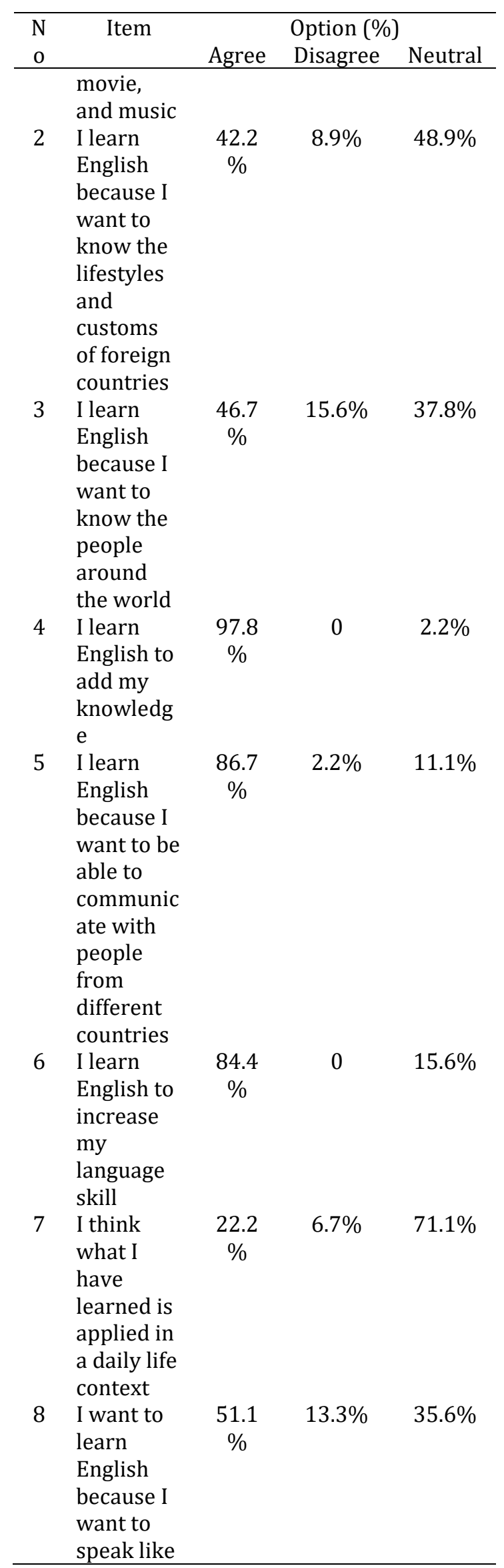

\begin{tabular}{|c|c|c|c|c|}
\hline $\mathrm{N}$ & \multirow[t]{2}{*}{ Item } & \multicolumn{3}{|c|}{ Option (\%) } \\
\hline 0 & & Agree & Disagree & Neutral \\
\hline & $\begin{array}{l}\text { native- } \\
\text { speaker }\end{array}$ & & & \\
\hline 9 & I learned & 71.1 & $6.7 \%$ & $22.2 \%$ \\
\hline & $\begin{array}{l}\text { English to } \\
\text { get a job } \\
\text { with good } \\
\text { salaries }\end{array}$ & $\%$ & & \\
\hline 1 & I learned & $80 \%$ & $4.4 \%$ & $15.6 \%$ \\
\hline 0 & $\begin{array}{l}\text { English to } \\
\text { support } \\
\text { my future } \\
\text { career }\end{array}$ & & & \\
\hline
\end{tabular}

Table 3. above presents that $64.4 \%$ of students learned English to understand books, journals, news, speech, movie, and music. Furthermore, $42.2 \%$ of students were attentive to foreign lifestyles and customs. It is in line with the result that $46.7 \%$ of the students want to know people worldwide. Besides, $86.7 \%$ wanted to communicate with foreigners, and 51.1\% wanted to speak English like nativespeaker. Moreover, almost $98 \%$ of ESP Social and Political Science program students agreed that learning English could add their knowledge through developing language skills to support their future careers.

Based on the findings above, it can be concluded that the students are primarily motivated to learn ESP. They declared that the mastery of ESP is helpful for their study. It will help them understood the development of social and political issues. $80 \%$ of the student replayed that they will use English in their future work. This argument agrees with $\mathrm{Wu}$ (2014) who claims that studying ESP is for technical work purposes. ESP learning is a subject that can help the students prepare themselves to be ready to work in certain fields.

Another result discovered from this study is $22.2 \%$ of students' assumption about English is not mostly applied in their daily life context. Students also overlooked a significant point in ESP learning: English is not 
taught as a separate topic from the students' everyday lives, but rather as part of a subject matter area. As a result, main items such as positive reinforcement and a learning plan are absent from the students' inventory (Souriyavongsa et al. 2013).

In terms of ESP learning technique, students were required to write and participate in oral activities relevant to many documents over the course of a semester. They learned how to read, write, and give an oral presentation about a social and political text. Therefore, the use of learning strategy attractively has important and advantages on students' achievement. Creating a positive learning atmosphere in the classroom is closely linked with objective goals and motivation. It is a kind of supporter who encourages them to do their best to achieve a satisfactory goal in their activity. Motivation is some internal drive that encourages somebody to pursue a course of action (Oroujlou and Vahedi 2011).

\section{Classroom Management}

The classroom management in ESP teaching is depicted in the table below.

TABLE 4. Students' Perception about Classroom Management

\begin{tabular}{lllcc}
\hline No & \multicolumn{1}{c}{ Item } & \multicolumn{3}{c}{ Option (\%) } \\
& & Agree & Disagree & Neutral \\
\hline 1 & $\begin{array}{l}\text { I know how } \\
\text { much I involve } \\
\text { in the } \\
\text { classroom }\end{array}$ & $57.8 \%$ & $2.2 \%$ & $40 \%$ \\
2 & & & \\
& $\begin{array}{l}\text { I know what I } \\
\text { have to achieve } \\
\text { in learning }\end{array}$ & $53.3 \%$ & 0 & $46.7 \%$ \\
& $\begin{array}{l}\text { English } \\
\text { I cooperate } \\
\text { with other } \\
\text { friends when a } \\
\text { group working } \\
\text { and doing the } \\
\text { task } \\
\text { The lecturer } \\
\text { pays attention } \\
\text { a lot to my } \\
\text { questions than } \\
\text { others }\end{array}$ & & & \\
\hline
\end{tabular}

\begin{tabular}{|c|c|c|c|c|}
\hline 5 & $\begin{array}{l}\text { I got much } \\
\text { guidance from } \\
\text { lecturer like } \\
\text { my other } \\
\text { friends }\end{array}$ & $46.7 \%$ & $15.6 \%$ & $37.8 \%$ \\
\hline 6 & $\begin{array}{l}\text { I got much } \\
\text { encouragement } \\
\text { from the } \\
\text { lecture while } \\
\text { learning } \\
\text { English }\end{array}$ & $75.6 \%$ & $2.2 \%$ & $22.2 \%$ \\
\hline 7 & $\begin{array}{l}\text { I got the } \\
\text { feedback from } \\
\text { my mistake }\end{array}$ & $84.4 \%$ & 0 & $15.6 \%$ \\
\hline 8 & $\begin{array}{l}\text { I got an equal } \\
\text { opportunity } \\
\text { like other } \\
\text { students to } \\
\text { involve in the } \\
\text { classroom }\end{array}$ & $82.2 \%$ & $2.2 \%$ & $15.6 \%$ \\
\hline 9 & $\begin{array}{l}\text { I got a score } \\
\text { from my work }\end{array}$ & $93.3 \%$ & $2.2 \%$ & $4.4 \%$ \\
\hline 10 & $\begin{array}{l}\text { I got the same } \\
\text { opportunity to } \\
\text { respond to the } \\
\text { lecture's } \\
\text { question as to } \\
\text { the other } \\
\text { students }\end{array}$ & $75.6 \%$ & $2.2 \%$ & $22.2 \%$ \\
\hline
\end{tabular}

Table 4. above demonstrates that nearly $60 \%$ of the ESP teaching-learning process included students. Mostly 85\% received much feedback to engage in learning, and $93.3 \%$ opportunity to get a score from the assignment. Around 60\% of them worked and cooperated in both group work and individual tasks. When studying in the classroom, $75.6 \%$ accepted that the lecture provided ample support, and $46.7 \%$ received feedback from the lecture in the same way that other friends did. Besides, $75.6 \%$ of students agreed that the lecture paid attention a lot to students' questions, and they had equal opportunities to respond to the lecture's questions.

Students should publicly discuss their issues, accomplishments, and overall process of learning a language as a socially oriented and socially situated practice in classroom management (Breen 1985). As a result, there are a variety of ways to improve practices in 
the ESP classroom (Belcher 2009). One of the lecture's approaches was using tasks inspired by real-life communicative activities; for instance, ESP students engage in role plays, group discussion, and presentation. Subsequently, the teacher gives feedback, score, and reward in order to appreciate students' competence. Another method is to use problem-based learning exercises, which are designed to get students working together to solve common field-specific problems. It is obvious that the students who were asked to read a journal social and political. Furthermore, they analyzed the issues which appear to be solved. These programs equip students with individual language learning strategies and problem-solving skills, preparing them to function in their target communities (Belcher 2009).

\section{Students' Difficulties in Learning ESP}

Some learning ESP issues were addressed in response to the second research query: firstly, they lacked vocabulary knowledge. These are the main and the largest obstacles for ESP students in the Social and Political Science program. According to the results of the interview, they find the foreign terms to be confusing. It makes the students confused to choose appropriate meaning related to the context. Some of the reasons for students' lack of vocabulary, according to Maruyama (1996): 1) The students thought they didn't need to learn words because they weren't used much, if at all, in their everyday lives.; 2) Therefore, they did not have the motivation to learn the words, and 3) Most English lectures could not teach them these words because the lectures were not well acquainted with these scientific terms. Many students also believed that because ESP words are rarely used in their everyday lives, they would be unmotivated to learn and remember them.

The second issue was that when discussing social and political science documents, the students had trouble pronouncing the sentences. It can be seen that their speaking when in the presentation was different from the meaning context. It should pay attention to the students to pronounce a word based on meaning or context. They should concern speaking and listening skills when the lecture gives two language lectures, native language, and English, in the classroom.

The other issue in ESP is that of the students' reading abilities. Agustina (2014) found that most students struggle to grasp the definitions of syntactic units while reading text. They didn't understand what a subordinate clause or passive forms were, for example. It was also noted that they had no difficulty comprehending the context, leading the researcher to believe that the students had language difficulties. The results of the interviews revealed that the students had a problem with syntactic units.

Reading text as a learning tool can also be used to learn and practice a variety of skills. In an ESP course, learning materials may be a source of new vocabulary, communicative, or writing skills. To make them work with a reading skill effectively, teachers need to combine reading text and writing. The students were asked to practice writing English text appropriately. These difficulties were also found in using grammatical patterns correctly. Learning ESP becomes difficult since the target language has a different system from the native language. According to DeKeyser (2005), its difficulty is influenced by a number of factors. There are meaning ambiguity, shape, and the relationship between meaning and form. Grammar is the part of the course that teaches ESP students how to understand the meaning of sentences and how to properly use vocabulary in ESP classes.

Associated with ESP students' perceptions of effective teaching methods applied by lecture, it was found that students have a preference of the characteristics of the lecture who 
stimulate the students' learning process and creating fun learning. Carlson et al. (2019) presented the lecture's quality component that can make teaching and learning successful or provide learning outcomes related to the target of learning achievement.

\section{CONCLUSIONS AND SUGGESTIONS}

The aim of this study was to find out how ESP students felt about the efficacy of ESP teaching and the challenges of studying ESP for the Social and Political Science curriculum. To answer the first question, the researcher classified the effectiveness of teaching ESP into four: Material design, instructional methods, learning motivation, and classroom management are all important factors to consider.

The findings indicated that the students had had positive attitudes toward ESP for Social and Political science. Most students considered the lecture's material to stimulate their motivation, although it was not easy for them. However, the lecture stimulated and encouraged the students in the teaching-learning ESP process. Concerning learning motivation, teaching ESP for Social and Political programs teaches language skills to prepare the students for their future careers. Following the classroom management, the students and the lecture actively overcame the ESP learning process's barriers. Additionally, it was found that the teaching strategies used by the lecture were supportive, provided feedback, giving a score, and professional guidance.

Some students' difficulties in learning ESP for the Social and Political Science curriculum, in response to the second research issue. The interview results showed that some students faced difficulties related to vocabulary, pronunciation, reading comprehension, grammatical structure, and English proficiency. Therefore, the teaching method of ESP for the Social and Political
Science program used by the lecture should be designed for positive learning. Creating positive learning is closely linked with motivation. Motivation is an important part of students' needs. It encourages them to learn ESP deeply.

\section{REFERENCES}

Agustina, Titik. 2014. "English for Specific Purposes (ESP): An Approach of English Teaching for Non-English Department Students." BETA 7(1):37-63.

Ahmed, Mohammad. 2014. "Issues in ESP (English for Specific Purposes)." International Journal for Teacher of English 4(1):36-59.

Akhiroh, Ninuk Sholikhah. 2017. "Teaching English in Non-English Departments: Empowering Teacher Towards Improvement." IJEE (Indonesian Journal of English Education) 4(1):49-62. doi: $10.15408 /$ ijee.v4i1.5341.

Alqahtani, Mofareh. 2015. "The Importance of Vocabulary in Language Learning and How to Be Taught." International Journal of Teaching and Education 3(3):21-34. doi: 10.20472/TE.2015.3.3.002.

Arnó-Macià, Elisabet, and Guzman Mancho-Barés. 2015. "The Role of Content and Language in Content and Language Integrated Learning (CLIL) at University: Challenges and Implications for ESP." English for Specific Purposes 37:63-73. doi: https://doi.org/10.1016/j.esp.20 14.06.007.

Basturkmen, Helen, and Rhonda Oliver. 2006. Ideas and Options in English for Specific Purposes. Mahwah, N.J: Lawrence Erlbaum Associates, Publishers.

Belcher, Diane, ed. 2009. English for Specific Purposes in Theory and 
Practice. Ann Arbor, MI: University of Michigan Press.

Bojović, Milevica. 2006. "Teaching Foreign Language for Specific Purposes: Teacher Development." doi: 10.13140/2.1.4011.4566.

Breen, M. P. 1985. "Authenticity in the Language Classroom*" Applied Linguistics 6(1):60-70. doi: 10.1093/applin/6.1.60.

Carlson, Janet, Kirsten R. Daehler, Alicia C. Alonzo, Erik Barendsen, Amanda Berry, Andreas Borowski, Jared Carpendale, Kennedy Kam Ho Chan, Rebecca Cooper, Patricia Friedrichsen, Julie Gess-Newsome, Ineke Henze-Rietveld, Anne Hume, Sophie Kirschner, Sven Liepertz, John Loughran, Elizabeth Mavhunga, Knut Neumann, Pernilla Nilsson, Soonhye Park, Marissa Rollnick, Aaron Sickel, Rebecca M. Schneider, Jee Kjung Suh, Jan van Driel, and Christopher D. Wilson. 2019. "The Refined Consensus Model of Pedagogical Content Knowledge in Science Education." Pp. 77-94 in Repositioning Pedagogical Content Knowledge in Teachers' Knowledge for Teaching Science, edited by A. Hume, R. Cooper, and A. Borowski. Singapore: Springer Singapore.

DeKeyser, Robert M. 2005. "What Makes Learning Second-Language Grammar Difficult? A Review of Issues: What Makes Learning L2 Grammar Difficult?" Language Learning 55(S1):1-25. doi: $10.1111 / \mathrm{j} .0023-$

8333.2005.00294.x.

Devlin, Marcia, and Gayani Samarawickrema. 2010. "The Criteria of Effective Teaching in a Changing Higher Education Context." Higher Education Research \& Development
29(2):111-24.

doi:

$10.1080 / 07294360903244398$.

Fatmawati, Fatmawati, Sofyan Gani, and Iskandar Samad. 2018. "Techniques for ESP Students in Teaching English." English Education Journal 9(4):513-26.

Fiorito, Lorenzo. 2021. "Using English." Teaching English for Specific Purposes (ESP). Retrieved (https://www.usingenglish.com/ articles/teaching-english-forspecific-purposes-esp.html).

Germizaj, Dr. Sc. Shykrane, and Dr. Sc. Shpresa Hoxha. 2014. 'Students' Perception of the ESP Courses at the University of Prishtina." ILIRIA International Review 4(1):363. doi: 10.21113/iir.v4i1.71.

Hyland, Ken. 2011. English for Academic Purposes: An Advanced Resource Book. Transferred to digital print. London: Routledge.

Maruyama, Hitoshi. 1996. "Difficulties in Teaching Technical English in Japan." Revista de Lenguas Para Fines Específicos 5(3):215-32.

McDonough, Jo, Christopher Shaw, and Hitomi Masuhara. 2013. Materials and Methods in ELT: A Teacher's Guide. Third edition. Chichester, West Sussex [England]; Malden, MA: Wiley-Blackwell.

Oroujlou, Nasser, and Majid Vahedi. 2011. "Motivation, Attitude, and Language Learning." Procedia Social and Behavioral Science 29:994-100. doi: 10.1016/j.sbspro.2011.11.333.

Poedjiastutie, Dwi, and Rhonda Oliver. 2017. "English Learning Needs of Esp Learners: Exploring Stakeholder Perceptions at an Indonesian Cuniversity." TEFLIN Journal 28(1):1-21. doi: http://dx.doi.org/10.15639/tefli njournal.v28i1/1-21. 
Rahmi, Rahmi, Abduh Abduh, and M. Sofyan. 2019. "Student Perception of ESP Business English Teaching Implementation in Makassar National Informatics Polytechnic." Jurnal Administrare: Jurnal Pemikiran Ilmiah Dan Pendidikan Administrasi Perkantoran 6(2):167-76. doi: https://doi.org/10.26858/ja.v6i2 .12514 .

Richards, Jack C. 2001. Curriculum Development in Language Teaching. 1st ed. Cambridge University Press.

Salkind, Neil J., and Kristin Rasmussen, eds. 2008. Encyclopedia of Educational Psychology. Thousand Oaks, Calif: Sage Publications.

Souriyavongsa, Thongma, Sam Rany, Mohamad Jafre Zainol Abidin, and Leong Lai Mei. 2013. "Factors Causes Students Low English Language Learning: A Case Study in the National University of Laos." International Journal of English Language Education 1(1):179-92. doi: 10.5296/ijele.v1i1.3100.

Syarifah, Firdha. 2017. "Lecturers' Understanding and Practice of Esp Material Development." English Language Teaching and Technology Journal 1(1):61-70.

Vong, Sam, and Wareerat Kaewurai. 2017. "Instructional Model Development to Enhance Critical Thinking and Critical Thinking Teaching Ability of Trainee Students at Regional Teaching Training Center in Takeo Province, Cambodia." Kasetsart Journal of Social Sciences 38:8895. doi: https://doi.org/10.1016/j.kjss.20 16.05.002.

Wu, Lin-Fang. 2014. "Motivating College Students' Learning English for
Specific Purposes Courses through Corpus Building." English Language Teaching 7(6):120-27. doi: 10.5539/elt.v7n6p120. 